\title{
INTRODUCTION
}

\section{Special section: religion and territorial politics in southern Europe}

\author{
Alberta Giorgi (iD ${ }^{\mathrm{a} *}$ and Xabier Itçaina ${ }^{\mathrm{b}}$ \\ ${ }^{a}$ Centro de Estudos Sociais, University of Coimbra, Coimbra, Portugal; ${ }^{b}$ Centre Emile Durkheim, \\ Sciences Po Bordeaux, Pessac, France
}

\section{The invisible politics of religion in southern European territories: preliminary considerations}

With this issue of Religion, State \& Society, we inaugurate a planned series of special sections focusing on the analysis of the political involvement of religious associations and organisations at the local level. Without pre-empting the more substantial conclusion that we plan for the last of the special sections, in this short introduction we aim to state briefly the main issues that will be covered by the selected articles. ${ }^{1}$

The relationship between religion and politics is a topic usually analysed either from a national or from an international perspective. Nevertheless, changes in contemporary political systems, in Europe and abroad, have reshaped the hierarchies between the local and the national spheres on a number of policies and issues. This has particularly been the case in Southern Europe where, over the last three decades, most of the countries have had to face several changes. First, religious change, which is the ongoing process of social secularisation, irrespective of denomination. Second, economic change, as a result of the major economic crisis in 2008. Third, political change: the burgeoning of new social movements and parties challenging the established party systems. We believe that national and transnational perspectives are useful, but insufficient to address properly the transformation of the interactions between religion and politics that have been induced by those changes. In religious matters, if the national state-church models still play an essential role in defining the regulatory framework for religions, we believe that observing the less visible interactions between politics and religion at the local scale is very necessary, for four main reasons.

First, it helps us to better understand the debates generated by the implementation of the national norms, but also to focus again on the public debates and controversies that have frequently anticipated the national debates and processes of institutionalisation. This is the case, for example, with controversies around the location of worship places, which have often triggered broader debates over the role of religion in national - and even European - identities. Politicised controversies on symbolic issues often take place at the local level: see the debates over the location of mosques in Italy (Allievi 2009; Bombardieri 2011; Conti 2012; O’Miel and Talpin 2013; Triandafyllidou 2006), the controversies surrounding the Muslim headdress in Spain (Burchardt, Griera, and García-Romeral 2014) and in Europe (Amiraux 2013; Ferrari and Pastorelli 2013; Koussens and Roy 2014) and, more broadly, issues dealing with religion in public spaces.

Second, the process of Europeanisation has resulted in the rescaling of government tasks, and contributed to the pluralisation of both the actors and the legal regimes able to

*Corresponding author. Email: albertagiorgi@ces.uc.pt 
play a role in governing diversity, especially at the local level. In this direction, the rescaling process opens variously articulated and differently accessible windows of opportunity for the claims of religious actors, in a pluralisation of venues and arenas wherein the configuration of actors varies, and in concomitant constraints and opportunities. This is the case with courts, whose role in religious governance has been increasing (de Galembert and Koenig 2014). An interesting example is the European Court of Human Rights, an international arena that may represent a window of opportunity for weak or underrepresented actors, like religious organisations, to overcome national veto players (Anagnostou and Millns 2013; Jacquot and Vitale 2014). Other venues that are likely to play a major role in the near future are local regulatory bodies (Grigolo 2010), which rule over policy fields that may have an impact on religious governance, such as urban planning.

Third, and more specifically, both the processes of devolution and subsidiarisation of a number of non-religious policies and the cooperation between private (for- and non-profit) and public organisations (in particular in social services) in a horizontal governance perspective have increased the importance of local politics (Kriesi 2008). The local scale is particularly relevant as constituting the arena where public authorities, private actors and religious and secular third-sector organisations manage - or not - to constitute efficient governance networks (Klijn and Skelcher 2007) in the welfare field. These local arrangements constitute an implicit form of regulation of public life by religious actors that, in some cases, might not coincide exactly with the sociopolitical preferences of the religious central authorities. They also raise, particularly in the field of welfare, the issue of the externalisation of social services from public welfare institutions to third-sector organisations. In this context, a focus on the changes in local contexts - in terms of economy, politics or policy arrangements - may offer an opportunity for pointing out the specificities of the relationships between state and religions at the local level, as both a scale of government and a specific arena. Indeed, the local level should be reconceptualised as a node in a network of multiscalar processes, in which the scaling may refer to either national or global processes of localisation and generalisation, as well as to specifically local dynamics. From this perspective, the 'local' calls for specific analytical frames, able to interpret its features and meanings (see Sassen 2006).

Fourth, grassroots religious organisations and associations have an important and increasing political role in Southern Europe on rather unexpected issues: movements for public water in Italy (Fantini 2014), mobilisations against discrimination, renewed engagement of religious associations in politics and in antiausterity protests and the issue of climate change. Paradoxically, these mobilisations have generated new proximities between some religious actors and the new social movements, while at the same time, majority Churches - the Orthodox Church in Greece, but also the Catholic Church in Latin countries - have been under serious criticism in the context of the European budgetary crisis, because of issues such as their tax benefits, properties and advantages in the educational systems. Again, these ambivalent relations between social movements and religious organisations need to be observed at the local level, where grassroots mobilisations take shape.

While research should focus on local issues, policymaking and mobilisation, this does not mean that the national and transnational scales should be neglected. Instead, research should focus on the constant interactions between the different scales of collective action and policymaking. It thus might be more appropriate to refer to the territory rather than to the local. Following Ruggie (1993), Smith $(2011,469)$ defines territory as an institutionalised geographical space, namely a space based on a stabilised set of rules, norms and 
expectations. From such a constructivist approach, the interactions between religion and politics are seen as moving within a constantly changing configuration of scales, territories and institutions.

This first special section comprises two contributions. Xabier Itçaina, in his article on Catholic organisations and territorial welfare in the Basque country and Emilia Romagna, analyses the economic crisis as a constrained opportunity for the increasingly central role of religious organisations in the welfare field. In both territories, the economic crisis and the liberalisation of welfare - and particularly the outsourcing of care services - have brought religious organisations back to the front line, this time as third-sector organisations, partially reversing the sidelining which the secularisation of welfare had produced. His work shows that the creative agency of religious actors has expanded to include the promotion of solidarity economy. Alberta Giorgi and Emanuele Polizzi explore the possibility of reading the change of religious organisations and activities in the light of the transformations of political governance, by focusing on the multilevel action of a religious organisation of Italian origins (Comunione e Liberazione (CL)). The political success of a Catholic movement in a Western democracy shows the possible role of substitution for traditional political movements in countries where distrust towards politics is on the rise. On the other hand, the story of CL in Lombardy suggests that we should look more closely into the changing hierarchy of local and national powers, which opens new windows of opportunities for actors mainly active at the local level. The two papers highlight the importance of taking into account changes in political and economic contexts for the analysis of religious actors. The authors also address the complex interplay between religion, economy and politics, which invites us to rethink the meaning and features of political secularism at the local level, where the boundaries between politics and religion are permeable and blurred.

\section{Disclosure statement}

No potential conflict of interest was reported by the authors.

\section{Note}

1. Earlier versions of some of the articles were discussed at the ECPR 2013 General Conference (Bordeaux, 5-7 September) and at the SISP 2013 Annual Conference (Florence, 19-21 September).

\section{ORCID}

Alberta Giorgi (D) http://orcid.org/0000-0003-2188-2682

\section{References}

Allievi, S., ed. 2009. Conflicts Over Mosques in Europe: Policy Issues and Trends. London: Alliance Publishing Trust.

Amiraux, V. 2013. "The 'Illegal Covering' Saga: What's Next? Sociological Perspectives.” Social Identities 19 (6): 794-806.

Anagnostou, D., and S. Millns. 2013. "Gender Equality, Legal Mobilization, and Feminism in a Multilevel European System." Canadian Journal of Law and Society/Revue Canadienne Droit et Société 28 (2): 115-131.

Bombardieri, M. 2011. Moschee d'Italia: il diritto al luogo di culto: il dibattito sociale e politico [Mosques in Italy: The Right to Places of Worship: The Social and Political Debate]. Bologna: EMI. 
Burchardt, M., M. Griera, and M. García-Romeral. 2014. "Narrating Liberal Rights and Culture: Muslim Face Veiling, Urban Coexistence and Contention in Spain." Journal of Ethnic and Migration Studies 41 (7): 1-20.

Conti, B. 2012. "L'émergence de l'Islam dans l'espace public." [The Emergence of Islam in the Public Space.] Archives de sciences sociales des religions 158 (2): 119-136.

de Galembert, C., and M. Koenig. 2014. "Gouverner le religieux avec les juges: introduction." [Governing Religion with Judges: An Introduction]. Revue française de science politique 64 (4): 631-664.

Fantini, E. 2014. "Catholics in the Making of the Italian Water Movement: A Moral Economy." Partecipazione e conflitto 7 (1): 35-57.

Ferrari, A., and S. Pastorelli. 2013. The Burqa Affair across Europe: Between Public and Private Space. Farnham: Ashgate.

Grigolo, M. 2010. "Human Rights and Cities: The Barcelona Office for Non-Discrimination and Its Work for Migrants." The International Journal of Human Rights 14 (6): 896-914.

Jacquot, S., and T. Vitale. 2014. "Law as Weapon of the Weak? A Comparative Analysis of Legal Mobilization by Roma and Women's Groups at the European Level." Journal of European Public Policy 21 (4): 587-604.

Klijn, E.-H., and C. Skelcher. 2007. "Democracy and Governance Networks: Compatible or Not?" Public Administration 85 (3): 587-608.

Koussens, D., and O. Roy. 2014. Quand la burqa passe a l'Ouest: enjeux ethiques, politiques et juridiques [When the Burqa Goes West: Ethical, Political and Legal Issues]. Rennes: PUR.

Kriesi, H. 2008. "Political Mobilisation, Political Participation and the Power of the Vote." West European Politics 31 (1-2): 147-168.

O'Miel, J., and J. Talpin. 2013. "Discutere lo spazio: come le pratiche partecipative toscane dividono la controversia rispetto alla localizzazione di una moschea a Firenze." [Discussing Space: How the Tuscan Participatory Practices Divided the Controversy over the Location of a Mosque in Florence.] Partecipazione e conflitto 6 (3): 5-29.

Ruggie, J. G. 1993. "Territoriality and Beyond: Problematizing Modernity in International Relations." International Organization 47 (1): 139-174.

Sassen, S. 2006. A Sociology of Globalization. New York: WW Norton \& Company.

Smith, A. 2011. "Territoire" [Territory]. In Dictionnaire des politiques territoriales [Dictionary of Territorial Politics], edited by R. Pasquier, S. Guigner, and A. Cole, 469-474. Paris: Presses de Sciences Po.

Triandafyllidou, A. 2006. "Religious Diversity and Multiculturalism in Southern Europe: The Italian Mosque Debate." In Multiculturalism, Muslims and Citizenship: A European Approach, edited by T. Modood, A. Triandafyllidou, and R. Zapata-Barrero, 117-142. Abingdon: Routledge. 